\title{
STYLOLITES: MEASUREMENT OF ROCK LOSS
}

\section{JOSE R. DE ANDRADE RAMOS}

\begin{abstract}
Stylolites are defined and their general characteristics summarized. A brief historical sketch of their origin is presented with emphasis on the three existing theories accepted by several authors. Microscopic, petrographic observations result in estimating calcareous rock loss by solution through the measurement of insoluble detrital residue that is concentrated within the stylolitic seams. Comparing these microscopic observations with Stockdale's figures, obtained by macroscopic measurements, it is concluded, like Stockdale, that some horizons may have been thinned as much as 40 to 50 per cent of their original thickness.
\end{abstract}

Keywords:

DEFINITIONS Stylolites area a "series of alternating, interpenetrating columns of stone which form an irregular, interlocked parting or suture in rock strata". (Stockdale 1922). The term stylolite applies to each individual, penetrating column. Where this parting is cut across, as in the wall of a quarry or in a hand specimen, it presents a rough, jagged line called stylolitic seam or stylolitic line. This line resembles somewhat the tracing of a stylus, hence the term applied to this geological structure. Vanuxem (1838), very reasonably, compared these lines to the sutures of the human skull.

Where the stone has been split along as stylolitic parting, an extremely irregular, pinnacled surface is presented. The term stylolitic surface might well be applied to this, and it could be defined as "a surface of contact marked by interlocking of mutual interpenetration of the two sides". (Pettijohn 1949, p. 156)

\section{GENERAL CHARACTERISTICS OF STYLOLITES a) The} teeth-like projections of one side fitting into sockets of like dimension on the other, commonly have a columnar aspect, b) The length of these columns varies from microscopic size to a foot or more, c) The stylolitic surface is variable in extension and position. It may diminish in relief, may bifurcate, may lie one upon another and may even penetrate another, d) The stylotitic seam is characterized by the concentration of the insoluble constituents of the rock, such as clay, iron oxide, quartz sand and other particles. This clay cap (oftentimes only minutely visible) rests at the end of the stylolitic projections, on both sides of the seam, e) Parallel fluting or striations on their sides characterize the columns. These striations resemble the slickensides of fault planes, f) In their most common occurrence, Stylolites are found in carbonate rocks and very rarely in sandstones (Price 1934), quartzite (Tarr 1916), gypsum (Stockdale 1936) and conglomerates. Stockdale (1943, p. 11) states that "ninety-nine per cent of all Stylolites are found in carbonate rocks, such as limestone, dolomite and marble".

TERMS APPLIED TO STYLOLITES The earliest mention of Stylolites was made in 1751, when they were described by Mylius as "schwielen" and were compared with petrified wood. The first mention of Stylolites in America was made by Eaton (1824, p. 134), who, considering the structures to be of organic origin, named them "lignilites". Vanuxem (1838), ascribing to Stylolites an origin due to the crystallization of Epsom salts, gave them the name "epsomites". Hunt (1863), accepting the explanation given by Vanuxem, used the term "crystallites". Scientists of do not use these terms today because they imply an origin that has not been confirmed.

The term "stylolite" was given by Kloden (1828) who thought the structure to be a distinct species of organism under the name Stylolites sulcatus. Kloden's term is now generally accepted because it suggests a meaning descriptive of the phenomenon.

Stockdale (1943) points out that "genuine Stylolites" must not be fogged by confusion with structures, which have vague resemblance, termed by him "pseudo-stylolites".

Brief historical sketch on the origin of Stylolites Ever since Stylolites were first mentioned the question of their origin has been under controversy. Numerous investigations of them have been made the most exhaustive and conclusive of these by German scientists. Several theories have been advanced for the origin of this conspicuous and intricate suturing or interpenetration of the adjacent parts of the same or adjoining beds.
The theories may be enumerated as follows: 1) organic theory (Eaton 1824); 2) crystallization theory (Bonnycastle 1831); 3) erosion theory (Plieninger 1852); 4) gas theory (Zelger 1870); 5) bitumen theory (Alberti 1858); 6) pressure theory (Quenstedt 1837); 7) solution theory (Fuchs 1894); 8) contraction-pressure theory (Shaub 1939), and 9) subaqueous-solution theory (Prokopovich 1952).

The earliest theories were quite hypothetical and presented little evidence for their support. The solution idea was first suggested by Fuchs (1894) and was strengthened soon by Reis (1902). It was extensively reviewed and studied by Wagner, in 1913, and further developed and crystallized by Stockdale. Stockdale published, in 1922, a comprehensive paper on the nature and origin of Stylolites, in which he gave an excellent resume of the previous theories and descriptions of the Stylolites from the limestone areas of Southem Indiana. He also included a bibliography of 88 titles on Stylolites and related subjects. While he is not the originator of the solution theory, Stockdale presented evidence to substantiate this theory.

Two theories of the origin of Stylolites have a divided following among today's geologists: the solution and the contraction-pressure theories.

The solution theory The solution theory contends that Stylolites result from differential chemical solution in hardened rock, under some pressure, on the two sides of a parting of some sort (such as a bedding plane, lamination plane, suture or crevice), the individual portions of the one side fitting into the dissolved out parts of the opposite, the interfitting taking place slowly and gradually as solution continues. According to this idea, Stylolites are a strictly secondary phenomenon developed after consolidation and hardening of rock material. The films of clay which cap the Stylolites are regarded as largely, if not entirely, residual - the insoluble constituents left from the dissolving of the stone. Accumulation of this residue along the stylolitic surface, in greatest amounts at the ends of the columns, "is best evidence of the solution origin of this feature." (Pettijohn 1949, p. 157). The striated slickensided-appearing sides of Stylolites are attributed in part to the slippage of one solid rock column past another. According to this theory, most commonplace development of Stylolites would be expected in calcareous, soluble rocks, such as limestone and marble. However, the theory does not preclude the less frequent existence of the feature in other kinds of strata (Stockdale 1936).

The contraction-pressure theory The contraction-pressure theory of Shaub (1939, pp. 53-54) holds that Stylolites originate while sediments are in the unconsolidated state from differential pressure and compaction which has compelled "transfer of material by plastic flow". Accordingly, Stylolites are a primary structure. To account for differential stresses necessary, the theory emphasizes the removal of pore water from sediments on top of an.original thin, clay band to bring about volume contraction. "The proximity of plastic material on one side of a soft clay band and less plastic material under differential horizontal stresses on the opposite side establishes conditions where the more plastic material will flow into the places where the pressure is reduced. The process of compaction is under gravitational control, hence the normal direction of the transfer of material by plastic flow will be approximately at right angles to the bedding. Where the more and less plastic materials are strongly influenced by dynamic forces, the flow may be in any direction. At the beginning of plastic flow from one side of a clay band to the other, the clay is sheared and carried 
ahead of the penetrating plastic material. The transfer of material by plastic flow under very low differential pressure between the adjoining beds is believed to be slow, orderly and usually non-turbulent. The transfer is accomplished in such a manner that little evidence of dragging is developed, except at the contacts. The gradual removal of pore water, and consequent gradual and continued volume contraction provide the necessary differential stresses for a prolonged transfer of material, which will continue until the stress differences become too low to overcome the resistance to plastic flow."

Shaub (1949, p. 35, fig.4) reproduced an interesting occurrence of stylolites illustrated and described by Logan (1863, p. 633, fig. 437) apud Shaub. It shows the manner in which the limestone stylolites penetrate a mass of chert in the Corniferous formation, near Port Dover, Canada. Criticizing the solution theory, Shaud asks: "... how, by all fair and unbiased deductions based on known facts, can one claim that the limestone columns in the chert were more resistant to solution than the chert?"

The subaqueous-soluction theory In December of 1952 Prokopovich presented a new approach to the solution of the origin of stylolites. The writer based his conclusions in field observations in Southwestern Germany, where he studied about 95 outcrops of the Muschelkalk and the Malm limestone, which are well known for their stylolites. He illustrated some curved columns with curved striations, and observed that "more often the stylolites cut fossils."

Against the solution theory he presents seven arguments. He states that "is often impossible" to explain the origin of columns which are curved or corroded, and narrowed at the bottom, by "partial resistance of solid rock." About the curved striations he adds: "The development of a partially curved striation in solid rock is impossible." (p. 218).

The contraction-pressure theory is likewise unsatisfactory to explain the facts observed by Prokopovich. He points out six arguments against this theory. The two more important facts are that the contraction-pressure idea fails to explain the origin of clay layers belonging to vertical seams, and that the cutting of fossils, the branching of seams, and the like, are all hard to explain by this hypothesis.

He concludes, "neither the pressure-solution nor the contractionpressure hypothesis can be used alone" to explain the origin of the stylolites. And states: "The stylolites were formed by solution in soft sediments." (Prokopovich 1952, p. 219).

Certain peculiarities noted in the stylolites investigated by Prokopovich are in accordance with the ideas expressed by various oceanographers. The solution of limestone, according to oceanographic studies, may be caused by changes of $\mathrm{pH}$, temperature, water circulation etc. To explain the cutting of fossils Prokopovich states: "The small turbulent currents in such a dynamic medium as water are very irregular. Such irregularities produce changes either in the form or location and size of columns or they may produce the cutting of fossils, gradation into undulations and other features that characterize stylolites... Curved stylolites, columns with narrowed bottoms, and undulations seams could be produced by the solution of walls, movement of water, and the force of gravity."

Discussing the mechanism of this subaqueous-solution theory, Prokopovich emphasizes the influence of the $\mathrm{pH}$ of seawater in the development of stylolitic seams, and states that stylolites "could take place two or three times during the sedimentation of one bed." According to this idea, stylolites are not a post-depositional structure.

Accepting the solution origin of the stylolites, without any further details in such mechanism, the author tried to add some statistical data about this peculiar geological structure.

\section{OBSERVATIONS Calculations of rock loss by solution}

Stockdale (1926) emphasizing the stratigraphic significance of solution, made some calculations of rock loss by solution. To secure quantitative data on the thinning of strata, he made a series of measurements in stylolitic rocks. Using all criteria in evidence for determining the amount of rock loss, such as number of prominent stylolitic seams, average length of stylolites, undulating stylolitic seams and the necessary amount and distribution of solution to produce such, he got the quantitative results as shown in Table 3 .

Detrital residue as a measure of rock loss Stockdale mentions, very often, the clay-like residual seams, as an important feature encountered in all stylolites, but he does not mention the detrital insoluble grains of silt size, that accumulate together with the clay-like materials, within the stylolitic surface. He states that "the residue from this type of rock solution... offers another means of measurement or rock loss through solution". (Stockdale 1926, p. 409). The procedure suggested by him, for such measurement, is based entirely in chemical analyses. He converts the percentages by weight of $\mathrm{CaCO}_{3}$ and "impurities" to percentages by volume of limestone and shale, obtaining, this way, a figure for the thickness of the residual cap.

Dr. Pettijohn, in one of his lectures, suggested that by knowing the concentration of insoluble grains in the rock body and in the stylolitic seam, a measure of rock loss could be established. Following his suggestion, and dealing with only one thin section available (SR-64), from the Warrior limestone of Pennsylvania, the Author attempted to get some quantitative data on the thinning of strata of that rock. The stylolites are very conspicuous, cutting calcareous oolites and with a great amount of residual detritus.

The thin section was divided in half-centimeter squares and counted quartz and plagioclase grains both in the rock body and accumulated in the stylolitic seams. Muscovite detritus can also be seen; but they were disregarded because of their minor importance.

Figure 1 shows the quartz-plagioclase ratio as obtained from the direct microscopic observation. Since the conclusions are raised without distinction between quartz and plagioclase. Figure 2 shows the added amount of these two kinds of grains in the observed areas.

Figure 3 gives a better idea of the insoluble grains distribution. The small stylolitic seam designated $\mathrm{C}$, testifies the accuracy of such method of rock loss measurement. Figure 4 gives the estimated concentration of detritus by square centimeter. As we can see, the concentration in detrital grains is not uniform through all the section.

CONCLUSION We can assume that solution dissolved the same amount of rock in both sides of the stylolitic surface. We can assume, also, that, in extreme cases, the solution took place only in one side of the stylolitic seam. The amount of rock dissolved in all these assumed cases are shown in Table 1. Calculating a hypothetical average concentration of insoluble grains, for the entire thin section, we would have 98 grains per square centimeter. It was included in the same table
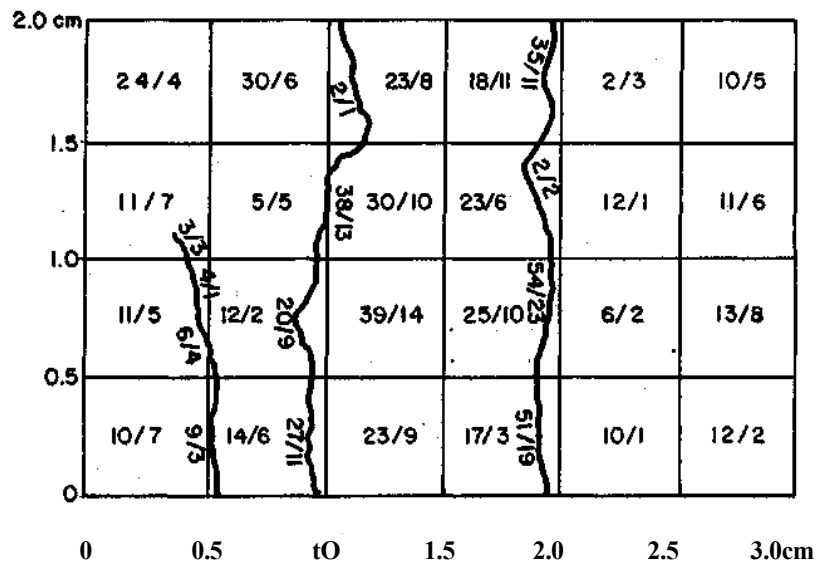

Figure 1 - Quartz/plagioclase ratio obtained from direct microscopic observation.

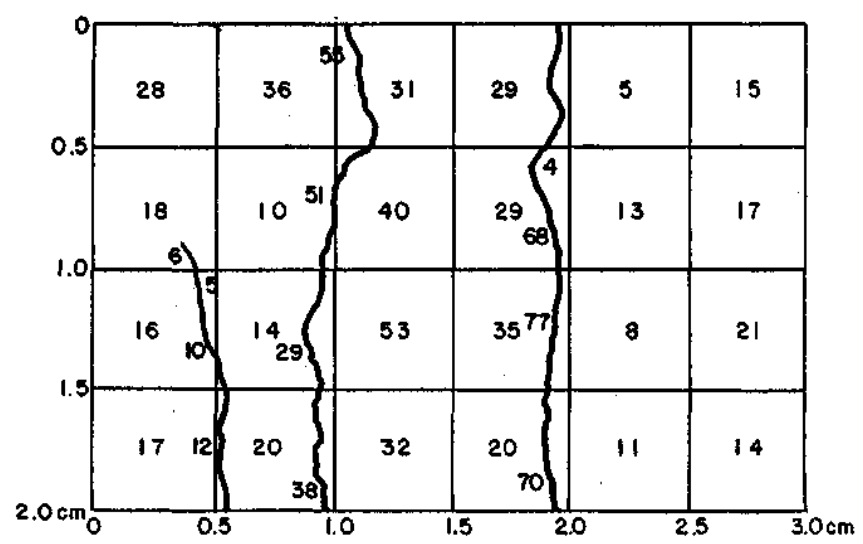

Figure 2 - Added amount of quartz grains in observed area. 


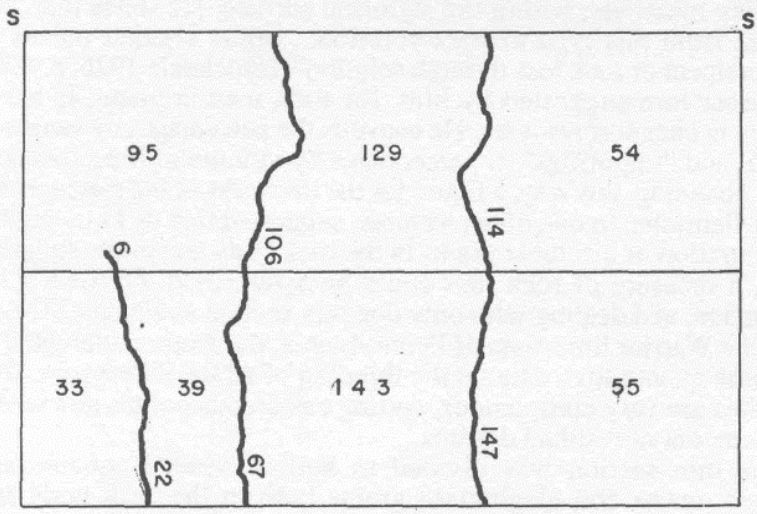

C B

Figure 3-Insoluble grains in the thin section.

B

\begin{tabular}{|l|l|l|}
\hline $95 / \mathrm{cm}^{2}$ & $146 / \mathrm{cm}^{2}$ & $52 / \mathrm{cm}^{2}$ \\
\hline
\end{tabular}

Figure 4 - Estimated concentration of detritus per square centimeter.

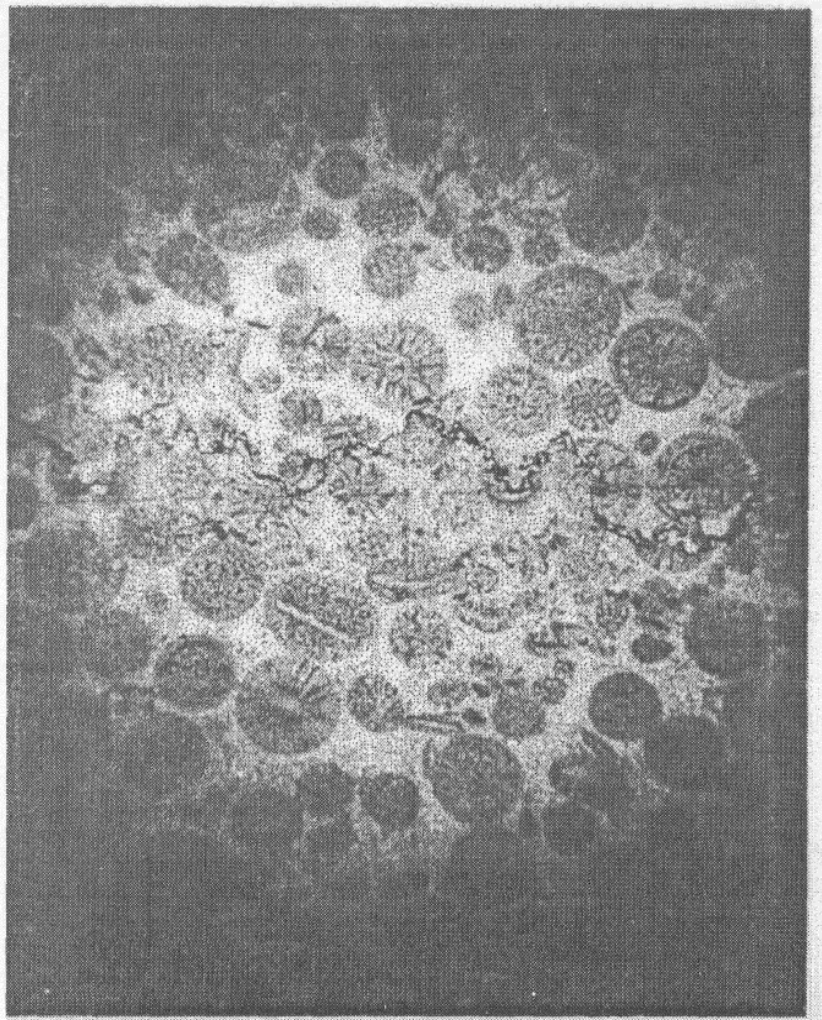

Figure 5 - Photomicrograph, middle stylolitic seam, large picture. Parallel nicols. Enlargement: 24 times (objective 3 and occular 8)

the amount of solution of such average rock. Several other cases may be considered in order to establish a gradational variation of detrital grain concentration through all the section, and consequent different dissolved portions. Taking the values that rise to extreme possibilities, and calculating the percentage of rock loss, we would have the results of Table 2. Comparing (see Table 3) the percentage of minimum loss, obtained by microscopic observations (Ramos), with Stockdale's figures (Stockdale 1926, pp. 405-407), obtained by macroscopic measurements, also referred to a minimum possible loss testified by the evidence, it seems reasonable Stockdale's statement that "some horizons may have been thinned as much as 40 to 50 per cent." (p. 406).

\begin{tabular}{|c|c|c|c|c|}
\hline Seams & \multicolumn{5}{|c|}{ Portions dissolved (in cm) } \\
\hline & $\begin{array}{l}\text { Equally in both sides } \\
\text { of the seams }\end{array}$ & Right sides of the seams & Left sides of the seams & $\begin{array}{l}\text { Hypothetical average } \\
\text { concentrate rock }\end{array}$ \\
\hline A & 1.3 & 2.0 & 0.9 & 1.3 \\
B & 0.7 & 0.6 & 0.9 & 0.9 \\
\hline
\end{tabular}

Table 1 - Amount of rock dissolved in four assumed cases.

Table 3-Percentage of minimum loss, obtained by microscopic observations (Ramos) and macroscopic measurements (Stockdale's figures)

\begin{tabular}{|l|l|c|c|}
\hline & \multicolumn{1}{|c|}{ Stylolitic rock } & $\begin{array}{c}\text { Amount of stone } \\
\text { measured } \\
\text { (in cm) }\end{array}$ & $\begin{array}{c}\text { Percentage of } \\
\text { approximate minimum } \\
\text { loss }\end{array}$ \\
\hline & $\begin{array}{l}\text { Columbus limestone } \\
\text { (Middle Dev.), Central Ohio } \\
\text { Salem limestone } \\
\text { (Bedford ls.), Southern Indiana } \\
\text { STOCKDALE } \\
\text { (macroscopic } \\
\text { observations) }\end{array}$ & $\begin{array}{l}\text { Carthage marble } \\
\text { (Lower Miss.), Missouri } \\
\text { Idem }\end{array}$ & $\begin{array}{l}\text { More than } \\
5 \%\end{array}$ \\
\hline $\begin{array}{l}\text { Tennessee marble } \\
\text { (Holston form.), Tennessee }\end{array}$ & 121.4 & $12.6 \%$ \\
\hline $\begin{array}{l}\text { RAMOS } \\
\text { (microsc.) }\end{array}$ & $\begin{array}{l}\text { Warrior limestone } \\
\text { (Mid.-Up. Cambrian), } \\
\text { Pennsylvania. }\end{array}$ & 365.8 & $22.4 \%$ \\
\hline
\end{tabular}

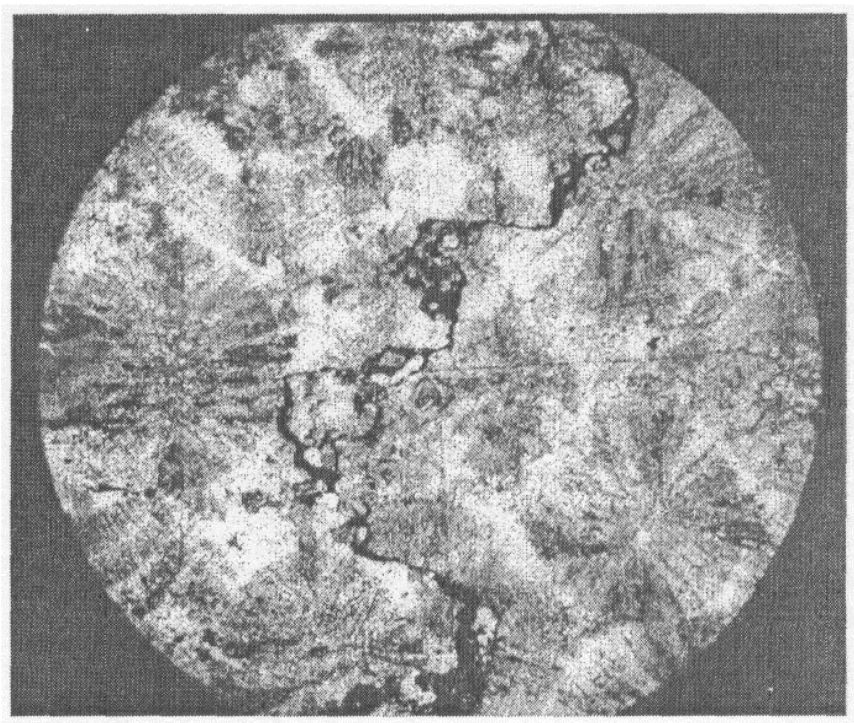

Figure 6 - Detail of the middle stylolitic seam, small picture. Crossed nicols Enlargement: 80 times (objective 10 and ocular 8)

One thin section (SR-64) of the Warrior limestone was thoroughly examined. The thin section was made with the Micro Tessar Lenz (different focus lens), and it belongs to Dr. Pettijohn's collection. In order to illustrate the method developed in this paper we present two photomicrographs (Figs. 5 and 6)

Acknowledgements To two anonymous referees of RBG for the critical review of the manuscript. 


\section{References}

Alberti R.V. 1858. Ueber die Enststehung der Stylolithen: Johresh. D. Verein f.vaterl. Naturk. in wurttemberg, p.292

Bonnycastle R.H. 1831. Continuation of the essay on the transition rocks of the Cataraqui. Am.Jour.Sci., 20:74-82

Eaton A. 1824. Report on the District Adjoining the Erie Canal. Geology of New York, p. 134.

Fuchs, Theodor 1894. Ueder die Natur und Entstehung der Stylolithen. Stizungsber. d. k. Akad. d. Wjss Math. - nat. Kl. Wien, Bd. 103, 673-688.

Hunt T.S. 1863. Geological Survey of Canada. Report of Progress from Its Commencement to 1865 , p. $631-634$.

Kloden F. 1828. Beitrage zur mineral.u.Geol.Kenntniss.der Mark Brandenburg, Bd. 1, p.28.

Pettijohn F. J. 1949. Sedimentary Rocks. Harper \& Bros., New York.

Plieninger 1852. Ueber Stylolithen: Jahresh. d. Verein. f. vaterl. Naturk. in Wurttemberg, p.

Price P.H. 1934. Stylolites in sandstone. Jour. Geol., 42:188-192.

Prokopovich N. 1952. The origin of stylolites. Jour. Sed. Petrology, 22:212-220.

Quenstedt A. 1837. Die Stylolithen sind anorganische Absonderungen. Wiegmann's Arch., $137-142$

Reis O. M. 1902. Ueber Stylolithen, Dutenmergel und Landschaftenkalk. Geognost. Jahresh. d. k. bayer. Oberbergamt in Miinchen, Bd. 15. 157-279.
Shaub B. M.I 939. The origin of stylolites. Jour. Sed. Petrology, 9(2):47-61

Shaub B. M. 1949. Do stylolites develop before or after the hardening of the enclosing

rocks. Jour. Sed. Petrol., 19:26-36.
Stockdale P.B. 1922. Stylolites: their nature and origin. Indiana Univ. Studies, v. 9, study

n.55, 1-97.
Stockdale P.B. 1926. The stratigraphic significance of solution in rocks. Jour. Geol., 34:399414

Stockdale P.B. 1936. Rare stylolites. Aw. Jour. Sci., 32(188): 129-133.

Stockdale P.B. 1943. Stylolites: primary or secondary?. Jour. Sed. Petrology, 13:3-12.

Tarr W.R. 1916. Stylolites in quartzite. Science, 43:819-820.

Vanuxem L. 1838. Geology of New York. Second Ann. Rept., 271.

Wagner G. 1913. Stylolithen und Drucksuturen. Geologische und Palaeontologische

Zelger B. 1870. Ueber Stylolithen: N. Jahrb. f. Mineral., p. 833.

Contribution IGC-059

Received February 3, 2000 Accepted for publication May 3, 2000 